\title{
HAVING A SAY: 'ACCESS TO JUSTICE’ AS DEMOCRATIC PARTICIPATION
}

\author{
Jennifer A Leitch *
}

\begin{abstract}
Despite the pervasiveness of civil law in Western societies and the impact of its judicial creation and administration, citizens are too often bystanders in litigation; they are either represented by lawyers, and/or increasingly required to resolve these problems themselves without the assistance of legal representation. In terms of access to justice policy and initiatives, the response to this critical problem represents one of the most contested issues on the law-and-society agenda and there have been continuing debates over the meaning of access, its objectives, and its success. The question that arises in this regard is pertinent - can access to justice initiatives empower individuals to meaningfully participate in the legal decisions and processes that affect their lives and by extension, the democratic process? This paper critically examines whether, given the structure of the civil justice system, participation by self-represented litigants is a legitimate or viable foundation for access to justice initiatives.
\end{abstract}

\section{A. INTRODUCTION}

We live in an era in which private law and public law regulate a broad range of every day activities of life. Many aspects of citizens' lives and the problems that an individual experiences in a modern bureaucratic society incorporate a legal dimension. ${ }^{1}$ Elements of personal injury, consumer relations, and debt, as well as almost all areas of economic and social interaction are regulated by the law. In a common law system, decisions about familial relationships, housing, and employment made in the traditional legal institutions, such as civil law courts as well as various regulatory and/or administrative regimes, are just some of the types of decisions that can affect individuals' lives in significant ways. Courts 'create a body of law that directly governs and indirectly guides, through both the full light and the shadow of the common law, much of what we do in our daily lives, including both individuals and corporate action'. ${ }^{2}$ Notwithstanding the pervasiveness of civil law in our society and the impact of its creation and administration on our lives, the reality is that citizens are too often bystanders in such matters; they are either represented by lawyers, and/or required to resolve

\footnotetext{
* Jennifer A Leitch (BA, LLB, LLM) PhD Candidate, Osgoode Hall Law School, York University, Toronto, Canada. I would like to thank Janet Mosher and Allan Hutchinson for their support and ideas. Any errors remain my own.

${ }^{1}$ Ab Currie, 'A National Survey of the Civil Justice Problems of Low and Moderate Income Canadians: Incidences and Patterns' (April 2005); There are legal issues for which many individuals do not have formal legal assistance and there are problems that they do not even characterise as legal problems or are unaware or unable to address as legal problems and thus end up 'lumping'. See William F Felstiner, Richard L Abel and Austin Sarat, 'The Emergence and Transformation of Disputes: Naming, Blaming and Claiming...' (1981) 15 (3/4) Law \& Society Review 631.

${ }^{2}$ Trevor CW Farrow, Civil Justice, Privatization and Democracy, (University of Toronto Press 2014), 251.
} 
these problems themselves without the assistance of legal representation. In effect, the history of court processes and the development of law within these court processes has involved a stylised conversation between elite judges and lawyers from which ordinary citizens were typically excluded and, even if included, with which those ordinary citizens had little familiarity or dexterity.

As a 'retrospectively looking public dispute resolution system, as well as a predictable, accessible, and just prospectively looking common law based-regulatory regime', superior courts 'clearly play a central regulatory role in rule-of-law-based democracies'. ${ }^{3}$ Consequently, it is acknowledged that law-making by courts is a historical and institutional fact of common law jurisdictions. ${ }^{4}$ As such, it is vital that as many citizens as possible play meaningful and informed roles in the process. ${ }^{5}$ However, with respect to the courts' lawmaking function, there is ongoing debate and discussion about both the legitimacy and effectiveness of this function from a democratic perspective. ${ }^{6}$ More specifically, there is a criticism that the courts should adhere to a policy of judicial restraint in decision-making in recognition of the supremacy of the elected bodies' law-making powers.

Pursuant to this critique, the engagement by courts in law-making processes is illegitimate and undemocratic. Antithetical to this criticism is a further critique that challenges the ability of the existing court system to affect positive social change and instead, through its law-making function, maintains existing power relationships. ${ }^{7}$ A later section of this paper engages in a further critical examination of the role of the civil justice system in a democratic society. Notwithstanding the critiques proffered in respect of the role that courts do or should play in a liberal democracy, one of the pressing challenges in a society that claims to be democratic is to bring the work of the courts as much as possible in line with the demands and disciplines of democratic principles and practice. This challenge has become particularly relevant given the fact that a significant number of individuals are compelled to

\footnotetext{
${ }^{3}$ Farrow (n 2) 252.

${ }^{4}$ Peter Gabel and Paul Harris, 'Building Power and Breaking Images: Critical Legal Theory and the Practice of Law' (1982-83) 11 Review of Law \& Social Change 369, 406-407; Farrow (n 2).

${ }^{5}$ In her article on the lawyer's role in promoting deliberative democracy, Carrie Menkel-Meadow suggests that the value of participation which is articulated by the fact that 'legitimate laws are authored by the citizens who are subject to them', is a central consideration in any discussion of modern political decision-making. Carrie Menkel-Meadow, 'The Lawyer's Role(s) in Deliberative Democracy (February 5, 2005) Georgetown University Law Center, Public Law \& Legal Theory Research Paper Series (research Paper No 784530), available online at http://ssrn.com/abstract=784530.

${ }^{6}$ Gabel \& Harris (n 4) 370.

${ }^{7}$ Lucie White, 'To Learn and Teach: Lessons from Drefontein on Lawyering and Power' (1988) Wisc L R 699; Gabel \& Harris (n 4) suggest that the legal system represents an important public arena in which the State attempts to legitimate the existing social order - a social order from which many individuals are alienated and disengaged.
} 
enter this process overwhelmed and under-prepared. This strongly suggests a crucial failing in democratic governance. Moreover, this troubling state of affairs is particularly acute in the case of self-represented litigants and, thus, has important implications for access to justice.

In terms of the state of legal self-representation, one recent report in Ontario suggests that approximately $40 \%$ of civil law litigants represent themselves; this percentage increases dramatically in certain legal fields such as family law where the percentage is as high as 60$70 \% .{ }^{8}$ Moreover, as retainers run out and clients are unable to pay their mounting legal bills, the percentage of self-represented litigants also increases. ${ }^{9}$ Low and moderate-income individuals are disproportionately among those likely to be self-represented. ${ }^{10}$ The American scholar Deborah Rhode has suggested 'the poor experience more legal difficulties than the average [person]' and are less likely to be in a position to address their problems without assistance. ${ }^{11}$ In this regard, empirical research has demonstrated that there is a strong link between unresolved legal problems and social exclusion. ${ }^{12}$ Social exclusion is, in turn, both a cause and effect of individuals experiencing justiciable problems. More often than not, these individuals experience a combination of problems that include 'unemployment, poor skills, low income, poor housing, high crime and family breakdown'. Alone or in combination, these problems perpetuate disempowerment and alienation, thereby making it difficult for individuals to resolve issues on their own and almost impossible to affect justice in their lives. ${ }^{13}$ Furthermore, this disempowerment and corresponding inability to access justice in order to address their issues or problems leads to individuals' continued disengagement from the law-making and law-administering processes that impact their lives in a myriad of ways. This disengagement de-legitimises the authority of the legal system, the rule of law and broader principles of democracy. In light of the cyclical nature perpetuated by a lack of access of justice, these consequences can be particularly severe for individuals who are already marginalised in society.

\footnotetext{
${ }^{8}$ Julie MacFarlane, 'Identifying and Meeting the Needs of Self-Represented Litigants', Final Report of the National Self-Represented Litigants Project (May 2013) 86.

${ }^{9}$ Ontario Bar Association, 'Getting it Right-The Report of the Ontario Bar Association Justice Stakeholders Summit' (June 2007).

${ }^{10}$ Although low and moderate-income individuals are disproportionately self-represented, recent empirical research in Canada suggests that $50 \%$ of the self-represented litigants interviewed had a university degree and approximately $40 \%$ of those interviewed had an income of over $\$ 50,000$ per year. This appears to suggest that the demographics of self-represented litigants may be changing. MacFarlane (n 8) 8.

${ }^{11}$ Deborah L Rhode, Access to Justice (OUP 2004) 103.

${ }^{12}$ Melina Buckley, 'Moving Forward on Legal Aid: Research on Needs and Innovative Approaches' (Report for the Canadian Bar Association June 2010) 40.

${ }^{13}$ ibid.
} 


\section{B. THE DEMOCRATIC THESIS OF ACCESS TO JUSTICE}

The response to these critical problems in terms of access to justice policies and initiatives represents one of the most contested issues on the law-and-society agenda. There have been continuing debates over its meaning, its objectives, and its success. One of the manifestations of these issues involves a more basic policy debate about the overall ambitions for access to justice - is the goal to improve people's access to the legal process (through various forms of legal representation) so as to increase their chances of achieving a more positive outcome in their individual legal matter (the practical thesis), or is it so as to enhance their participation and ultimately their ability to engage with law-making institutions and processes as well as concepts of justice as ends in themselves (the democratic thesis)?

The discussion about access to justice in this paper is premised on the democratic thesis. In accordance with this broader approach to access to justice, the means by which an individual participates span a spectrum from self-representation through to representation with the assistance of lawyers whose ambition and expertise are directed toward encouraging clients to share in the decision-making processes that affect them and enhancing their empowerment and participation. Unlike the practical thesis, which is more narrowly limited to the efforts necessary to achieve a favourable outcome in a particular legal matter through access to traditional legal representation, the democratic thesis is more broadly focused on encouraging individuals' engagement in law-making as well as law-administering institutions. In contrast to the traditional role and function of the lawyer and pursuant to the democratic thesis, the role of the lawyer is to facilitate the individual's engagement in the various decision-making processes that affect them. This role recognises that, within most democratic societies, lawyers are uniquely positioned to know the legal rules and processes as well as being trained to employ a particular type of reasoning that many individuals may need to understand in order to participate meaningfully. ${ }^{14}$

In accordance with this broader conceptualisation of access to justice, it is necessary to situate the discussion of access to justice theory and initiatives within the broader discourse about participatory democracy and the democratic benefits and objectives associated with

\footnotetext{
${ }^{14}$ While this is most often contemplated in the context of lawyers engaged with clients advocating social change, a democratic approach to access and by extension, lawyering is not limited to cases engaging issues of social justice. Gabel and Harris (n 4) argue that even in 'non-political cases' such as cases involving divorce, personal injury or unemployment - many of which will make up the bulk of many lawyers' practice - it is important that lawyers de-professionalise the lawyer-client relationship such that when confronted with the client's problem, the lawyer acts as an 'ordinary person with special experience - to emphatically comprehend these needs and help the client to articulate them in the most effective and meaningful way possible', taking account of the political nature of the conflict rather than characterising it as an abstract legal problem.
} 
increased citizen participation. In other words, participatory democracy is used as a lens through which to examine access to justice. Recent literature on the topic of access to justice highlights the fact that an important aspect of enhanced access should contemplate citizens being able to participate equally in the creation and administration of law. By contrast, the failure to promote participation leads to continued disengagement by the citizenry that is inconsistent with democratic principles, and among other concerns, leads to a corresponding loss of legitimacy in the legal institutions where law is made and applied. ${ }^{15}$ Based on the dual role of courts within 'rule-of-law-based democrac[ies]', there is a strong argument that access to justice theory should take account of direct citizen involvement in adjudicatory lawmaking processes. Thus, taking account of both the criticisms and the practical reality of the courts' law-making function, the focus of this paper is not to suggest that litigation (and the justice system more generally) is the only forum in which participation should be fostered but rather that, as a political process, it plays an important role in constructing and administering law in a democratic society and as such, it is legitimised by meaningful citizen engagement. Moreover, from a pragmatic standpoint, an approach to access to justice that is informed by principles of participatory democracy and focused on promoting meaningful participation by those engaged with the justice system is consistent with the evolving modern realities of selfrepresentation in that same justice system.

The question that arises in this regard is pertinent - can access to justice initiatives empower individuals to meaningfully participate in the legal decisions and processes that affect their lives and, by extension, the democratic process? However, prior to undertaking this analysis and offering some tentative suggestions for reform in the field of access to justice policy, it is necessary to canvas some of the principles associated with participatory democracy and to assess the criteria by which it might be possible to assess meaningful participation in the relevant legal processes and institutions. Thus, the goal of this paper is to examine access to justice theory and initiatives from the perspective of meaningful citizen participation, consistent with the principles of participatory democracy. In the next section, I will examine an emerging concept of access to justice that contemplates an expanded concept of access by individuals to the law-making and law-administering institutions in society. Following this, I will offer a brief review of the concept of participatory democracy including some of the objectives, benefits and challenges associated with enhanced citizen participation

\footnotetext{
${ }^{15}$ Janice Gross Stein and Adam Cook, 'Speaking the Language of Justice: A New Vernacular' in Julia Bass, WA Bogart and Frederick Zemans (eds) Access to Justice for a New Century-The Way Forward (The Law Society of Upper Canada 2005) 163.
} 
in a democratic society. The final section of the paper will explore the relationship between access to justice and the principles of participatory democracy and in so doing critically examine whether, given the structure of the civil justice system and the inherent weaknesses in that structure particularly as they relate to participation by self-represented litigants, meaningful participation is a legitimate or viable foundation for developing access to justice initiatives.

\section{THE EVOLUTION OF 'ACCESS TO JUSTICE' AS A MEANS TO PROMOTE GREATER CITIZEN PARTICIPATION}

In North America, scholars have characterised the development of access to justice theory and the corresponding initiatives that were shaped by these theoretical considerations as occurring in waves starting in the 1960s. ${ }^{16}$ The first wave saw the birth of poverty law and the development of 'storefront' legal clinics that were aimed at providing legal services to lowincome individuals. At this time, there was also a focus on procedural rights in criminal law and the development of civil rights litigation. ${ }^{17}$ The second wave of access to justice through the 1970s scrutinised the judicial system's performance regarding the procedures used in both the criminal and civil context, and in concluding that these procedures were sometimes slow, inefficient, and inconsistent, explored alternative dispute mechanisms outside the traditional justice system. ${ }^{18}$

Through the 1980s, a third wave of access to justice reforms focused on issues of equality and the development of substantive measures that were aimed at ensuring equality in legal outcomes as well as procedures. ${ }^{19}$ Through the 1990s, there was a growing recognition by legal scholars that access to justice would need to include access to non-traditional means of resolving disputes as well as provide better access to public legal education in order that citizens could understand their rights and responsibilities and gain access to the law-making

\footnotetext{
${ }^{16}$ Marc Galanter, 'Access to Justice in a World of Expanding Social Capability' (2010) Fordham Urb LJ 37 (1) 115

${ }^{17}$ Roderick MacDonald, 'Access to Justice in Canada Today: Scope, Scale and Ambitions' in Julia Bass, WA Bogart and Frederick H Zemans (eds) Access to Justice for a New Century-The Way Forward (Law Society of Upper Canada, 2005) 19

18 ibid 20. Laura Nader expresses a skepticism regarding the development of alternative dispute resolution (ADR) mechanisms as a means of resolving disputes outside the courtroom. Specifically, she questions whether instead of improving access to justice, ADR is in fact an unregulated process that is motivated by a desire to unburden the courts and control the populace, neither goal of which served the justice interests of the ordinary person. Laura Nader, 'Processes of Constructing (No) Access to Justice (For Ordinary People),' (1990) 10 Windsor YB Access Just 496, 511.

${ }^{19}$ MacDonald (n 17) 20-21.
} 
processes. ${ }^{20}$ It was during this time that government in Canada sought to "enhance citizen participation in Parliamentary committees and the rule-making hearings of administrative bodies in accordance with this expanded concept of access to justice'. ${ }^{21}$

Finally, the fifth and most recent wave of access to justice theory has built on and responded to some of the themes that have emerged over the past 30 years. The most recent approach to promoting access to justice contemplates enhanced access to the "myriad of unofficial institutions where law is made and administered' ${ }^{22}$ This broader concept of access to justice theory informs recent access initiatives, such as self-help legal services, and will form a basis for the present analysis. As Roderick MacDonald stated:

In a liberal democracy, true access to justice requires that all people should have an equal right to participate in every institution where law is debated, created, found, organized, administered, interpreted and applied. This means providing equal opportunities for the excluded to gain full access to positions of authority within the legal system. Improving access to legal education, to the judiciary, to the public service and the police, to Parliament and to various law societies is now seen as the best way of changing the system to overcome the disempowerment, disrespect and disengagement felt by many citizens. ${ }^{23}$

While this approach to access to justice represents a broader concept of what access should entail, there is still a tension between this broader concept that is focused on participation in a variety of legal and political institutions that impact individuals' lives, and a concept of access that is focused on providing individuals with access to lawyers and legal services as a means of obtaining justice. The existing paradigm about what access should include and how access achieves justice has largely focused on the belief that access to lawyers will assist individuals in getting a better outcome, which is typically defined as justice. Underlying this paradigm are certain assumptions about what people are believed to want from the legal system, namely to win their case. ${ }^{24}$ However, part of the explanation for a move toward broader conceptualisations of access to justice might lie in the corresponding shift away from the traditional dispute resolution process as the exclusive means by which individuals may

\footnotetext{
20 ibid 22.

21 ibid.

22 ibid 23.

${ }^{23}$ MacFarlane (n 8) 23.

${ }^{24}$ Susan Silbey and Sally Merry, 'What Do Plaintiffs Want? Re-Examining the Concept of Dispute' (1984) The Justice System Journal 9(2) 151
} 
obtain justice. ${ }^{25}$ In particular, limitations within the traditional dispute resolution framework challenge the idea that litigation is an appropriate forum for achieving social justice. ${ }^{26}$ Moreover, the evolution of alternative dispute resolution processes has provided individuals with an opportunity to have a more direct 'say' in the process and, in so doing, participate in the resolution of their legal issue in a manner that reflects their own concepts of justice. This is contrasted with the passive role traditionally played by clients in the court system.

In a legal context, the problems associated with disengagement and disempowerment are intertwined in the sense that individuals without access cannot impact the laws and policies that affect them and yet can be significantly influenced by the law's application in their life in a variety of intrusive ways. Thus, for scholars such as Janice Gross Stein, Lucie White and Marc Galanter, the goal of improved access must include engagement by all citizens in the legal and political processes that affect them as opposed to access that contemplates more reliance on legal professionals. In order to accomplish this, it is necessary that citizens, with the aid of legal information and advice, become able to participate directly in the development of a new language of law. This, in turn, further fosters citizens' ability to both understand and participate in the legal system. ${ }^{27}$

From a practical standpoint, the development of a new language of law necessarily involves the de-mystification of the law by making it less technical and more relevant to the ordinary citizens that it purports to regulate. ${ }^{28}$ It is this de-mystification of law and legal processes that contributes to the development of a new 'legal vernacular' through which citizens 'participate in redefining, reforming and shaping the law and its institutions' ${ }^{29}$. In contrast, the continued mystification of law and its processes is reinforced, in part, by a traditional approach to the practice of law whereby lawyers adopt certain roles characterised by a sense of objectivity and a need to re-constitute the client's political/social/economic

\footnotetext{
${ }^{25}$ The tension between a broader concept of access that focuses on participation and a concept that is focused on legal outcomes arises in the context of access to justice initiatives such as self-help for self-represented litigants. Self-help initiatives are broadly defined as the provision of legal advice and information to self-represented litigants by volunteer lawyers with the understanding that the self-represented litigants will continue to manage their own legal matter. In the particular context of self-help initiatives, this tension reflects the fact that there are legitimate practical concerns associated with self-represented litigants' ability to participate meaningfully in a judicial system that is both professionalised and designed by and for lawyers and judges. One of the responses to this concern involves a discussion about how the existing court systems and procedures as well as the key players in that system will need to be reshaped to better encourage and facilitate meaningful participation.

${ }^{26}$ White (n 7).

${ }^{27}$ Gross Stein and Cook (n 15) 170.

${ }^{28}$ Interestingly, there has been a recent trend in courts in downtown Toronto respecting the nature of draft orders prepared by judges following motions. Specifically, certain judges have begun to move away from the traditional legal language and format used in draft orders and instead engage plain language in order to ensure that the directions are understandable to those subject to the order.

${ }^{29}$ Gross Stein and Cook (n 15) 170.
} 
issue as an abstract legal issue. ${ }^{30}$ However, Lucie White suggests that the practice of law has cultural meaning and, as such, should include a dialogue about social justice. ${ }^{31}$ Thus, to the extent that individuals are able to move away from the traditional roles played by clients and lawyers and, in so doing, engage in these conversations in a more direct fashion, they may be able to participate in the development of legal norms of justice and equality that are reflective of their own lives and experiences.

In a similar vein, Benjamin Barber suggests that terms such as 'justice' are not to be understood as abstract terms, but rather as political values that cannot be apprehended or practised except in the setting of citizenship. ${ }^{32}$ Moreover, the concepts of democracy and justice are contingent and interdependent such that justice is not sustainable when delivered as a command and democracy is weak when it is restricted to counting votes as a means of obtaining a political outcome. ${ }^{33}$ Through democratic dialogue, terms such as justice become the subject of debate, challenge, valuation and transformation in accordance with the needs and circumstance of the particular political communities. ${ }^{34}$ This is not to suggest that the terms are only relative and relevant to the immediate will of the populace, but rather that the terms are truly reflective of a citizenship that has, through meaningful dialogue and deliberation, encapsulated certain ideas and perspectives. Within the context of access to justice, it is important to remember that in a modern democracy, a significant portion of this dialogue and deliberation concerning concepts such as justice and equality occurs in the justice system.

From the standpoint of access to justice, the question is whether the promotion of more direct participation by individuals consistent with a theory of participatory democracy could, in turn, contribute to the demystification of law and existing legal processes necessary to develop law that is more inclusive and reflective of the citizenry that it purports to regulate. This question also raises queries about whether the participation encouraged must necessarily be direct in the sense of individuals representing themselves or whether direct participation might also contemplate legal representation of individuals by lawyers.

In the context of self-representation, the influx of self-represented parties into the judicial system could advance the development of a 'new legal vernacular' developed by the

\footnotetext{
${ }^{30}$ Gabel and Harris (n 4) 407-409; Jurgen Habermas, Between Facts and Norms - Contributions to a Discourse Theory of Law and Democracy (MIT Press 1996) 411.

${ }^{31}$ White (n 7) 758.

${ }^{32}$ Benjamin Barber, Strong Democracy Participatory Politics for a New Age, (University of California Press Ltd 1984).

${ }^{33}$ Lani Guinier, 'Supreme Democracy: Bush v Gore Redux' (2002) 34 Loyola University Chicago LJ 23, 66.

${ }^{34}$ Barber (n 32) 156.
} 
very citizens that the law purports to regulate. As previously noted, an important component of the development of this 'new legal vernacular' necessarily includes the demystification of law and related legal processes. As such, the aspirations regarding the creation of a 'new legal vernacular' assume that there is a corresponding shift pursuant to which individuals are 'disabused of the tendency to confer undue authority on all kinds of experts' ${ }^{35}$ and a move away from the assumption that participation in legal institutions has historically been the exclusive domain of the legal profession. In this regard, the control exerted by the legal profession over the formation and interpretation of the law and the corresponding exclusion of ordinary citizens from the legal process has contributed to the continued reliance on legal professionals to define and obtain justice and the corresponding disengagement by citizens from the legal decision-making processes where justice is defined. ${ }^{36}$

Underscoring a broader approach to access strategy that contemplates a spectrum of initiatives is the concern that, in order to participate in legal processes and institutions in a meaningful manner, individuals will require different levels of assistance with procedural law, substantive law and even the application of legal reasoning. ${ }^{37}$ This is consistent with scholars such as Wexler, Simon, and Lopez who envisage a different role for lawyers; a role in which lawyers encourage and facilitate client engagement in the decisions about their case and in dialogue about law more generally. This type of lawyering is different from the traditional approach to lawyering in which lawyers as "professionally trained technical experts ${ }^{38}$ assume responsibility for their client's legal matters and the client, as a private citizen, remains in the background. Gabel and Harris suggest that the result of 'conveying this professional mystique to our clients, and by transforming the action that brought them to a lawyer into an abstract legal matter, we [lawyers] contribute to the clients' powerlessness'. ${ }^{39}$

In contrast to traditional ideas about lawyering and consistent with a broader conceptualisation of access, democratic or rebellious lawyers engage in non-hierarchical

\footnotetext{
${ }^{35}$ Allan C Hutchinson, The Province of Jurisprudence Democratized (OUP 2009) 199.

${ }^{36}$ Rhode (n 11).

${ }^{37}$ In re-constituting the lawyer's role when assisting clients with cases that involve issues of social justice, Lucie White discusses the value that lawyers can add as well as the goals associated with their assistance when she states 'nevertheless, fluency in the law - that is, a deep practical understanding of law as a discourse for articulating norms of justice and an array of rituals for resolving social conflict - will greatly improve a person's flexibility and effectiveness at 'third-dimensional' work. An understanding of law as discourse on norms will help him work with the clients to deepen their own consciousness of their injuries and their needs. Knowledge of the law's procedural rituals will give the group access to a central arena for public resistance and challenge'. White (n 7) 766. See also Russell Engler, 'Connecting Self-Representation to Civil Gideon: What Existing Data Reveals About When Counsel is Most Needed' (2010) 37(37) Fordham Urban Law Journal

${ }^{38}$ Gabel \& Harris (n 4) 407.

39 ibid 407.
} 
partnerships with clients whereby lawyers encourage client participation in the legal decisions and strategies that affect their cases as well as the implementation of these decisions. ${ }^{40}$ This approach is consistent with the democratic principle that 'no single person should have sole responsibility for making and implementing [such] decisions'. ${ }^{41}$ Lawyers and clients deliberate together to both frame the issue and then implement the decided-upon strategies in addressing the issue. One of the challenges for democratic lawyers as legal experts is to resist the temptation to take over the process when it becomes difficult or 'place pressure on subordinated groups to formulate their interests in forms that the law can process ${ }^{42}$ To do so would entail a reversion to a more formal representative democratic approach consistent with 'learned guardians in charge of tending to the interests of others without their active participation' ${ }^{43}$

Carrie Menkel-Meadow suggests that if democratic participation is a process to improve public order and social justice then lawyers, acting for parties or groups or by otherwise facilitating new participatory forums and procedures, have an important role in these processes. ${ }^{44}$ For example, in consensus-building processes that are aimed at enhancing participation in law-making and political decision-making, lawyers may be able to help in constructing participatory processes and facilitating the administration of these processes in order to ensure that all those wishing to participate are heard. ${ }^{45}$ Moreover, by engaging with lawyers, learning about various legal processes, and devising solutions to address their issues and concerns, clients relinquish their reliance on experts. ${ }^{46}$ In doing so, they begin to have a direct 'say' in the legal decision-making that affects their lives and, arguably, in law-making processes more generally.

\section{DEMOCRACY AND PARTICIPATION}

The essence of democracy is that it engages ordinary people in government and governance. ${ }^{47}$ It contemplates a 'regime of popular self-government which not only allows for, but relies upon participation by citizens in the formulation and enactment of laws that govern their

\footnotetext{
${ }^{40}$ Asciano Piomelli, 'The Democratic Roots of Collaborative Lawyering' [2006] 12 Clinical Law Review 541.

41 ibid 600; Gerald Lopez, 'Living and Lawyering Rebelliously' (2005) 73(5) Fordham Law Review 2041, 213.

42 White (n 7) 757.

${ }^{43}$ Piomelli (n 40) 602.

${ }^{44}$ Menkel-Meadow (n 5) 105, 112-115.

45 ibid.

${ }^{46}$ Ingrid Eagly, 'Community Education: Creating a New Vision of Legal Services Practice' (1997-1998) 4 Clinical L Rev 433, 445.

${ }^{47}$ Christian Welzel and Ronald Inglehart, 'The Role of Ordinary People in Democratization' (January 2008) 19(1) Journal of Democracy 126, 128.
} 
lives'. ${ }^{48}$ In its strong incarnation, therefore, democracy encompasses 'politics in the participatory mode where conflict is resolved in the absence of an independent ground through a participatory process of ongoing, proximate self-legislation and the creation of a political community capable of transforming dependent, private individuals in to free citizens and private interests in to public goods ${ }^{49}$ In furthering a concept of strong democracy, the question that arises is how best to increase the scope and nature of individuals' participation in the institutions, processes and decision-making that impact their lives.

Democracy in a participatory mode is not simply about conducting free elections in which every citizen is provided with the opportunity to vote. Rather it involves a 'diffuse and urgent hope that the people themselves can become moral and political actors in the civic fabric of our society'. ${ }^{50}$ Subject to casting votes in regularly scheduled elections, citizens in a representative system of democracy do not directly participate in the creation of the laws and policies that govern them. As a result, they become the 'passive constituents of representatives, who, far from reconstituting the citizens' aims and interests, usurp their civic function and deflect their civic energies'. ${ }^{51}$

By contrast, participation requires that citizens regularly and frequently engage in debate, deliberation and decision-making respecting the development of policy and deployment of power that impacts their collective lives. The presumption from a theoretical standpoint is that communication, dialogue, and deliberation by citizens and decision-makers will produce better and more legitimate outcomes. ${ }^{52}$ The assumption is not that the citizenry, as opposed to elected officials, will resolve all of the complicated issues that face modern democratic societies, but rather that citizens will participate through dialogue and deliberation and, in so doing, develop public ends that reflect the concerns and needs of the citizenry, as well as the collective normative value of concepts such as justice and equality. ${ }^{53}$ This development of public ends and expression of collective normative values is consistent with a community that is engaged in acts of collective self-government as opposed to representative government or, alternatively, a political system focused almost exclusively on individual needs.

\footnotetext{
${ }^{48}$ Hutchinson (n 35) 137.

${ }^{49}$ Barber (n 32) 132.

${ }^{50}$ Guinier (n 33) 27.

${ }^{51}$ Barber (n 32) 147.

${ }^{52}$ Carrie Menkel-Meadow (n 5) 106.

${ }^{53}$ Barber (n 32) 154-155. Participation in this mode contemplates a broad spectrum of activities and goals that range from the development of policy and law-making at one end of the spectrum to information exchange and deliberation of public issues at the other end of spectrum.
} 
In light of the objectives associated with participatory democracy, namely greater citizen engagement, the question that arises is whether these objectives are achievable within a representative democracy. Typically, in a representative democracy, elected politicians are entrusted to determine what is in the public's interest and as such, there is little or no further need for citizen engagement. ${ }^{54}$ This involves a distinction between individuals 'having a vote' in a representative democracy and individuals 'having a say' in the matters that affect them. ${ }^{55}$ From a practical standpoint, this distinction can be particularly significant in respect of policies that require that citizens play an active role in the administration of a specific policy initiative, such as disease control or environmental protection. ${ }^{56}$

Carole Pateman highlights the principles of participatory democracy and ultimately concludes that a theory of participatory democracy is built on a central assertion that individuals and institutions cannot be considered in isolation from one another. ${ }^{57}$ In answering the question of how greater citizen participation might evolve, Pateman suggests that there is a need for the social training of citizens in the ways of democracy in order to ensure that citizens are able to maximise their participation within a democracy. She envisions this training as occurring in many different spheres of society and involving ever greater acts of participation. The benefit of participating in different social and political spheres is that the individual develops 'attitudes and psychological qualities' that in turn foster further participation. ${ }^{58}$ Thus, one of the significant functions and effects of democratic participation is educative. In this regard, participation serves as a 'learning process that educates citizens with the skills needed to sustain democracy' including the skill necessary to both engage in political processes and be effective in those same processes. As individuals participate in making decisions and solving problems, they learn in an experiential manner that leads to changes in behavior, confidence and leadership. This, in turn, empowers individuals and allows them to expand the nature and scope of their participation. ${ }^{59}$

A key component of this process involves the individual as a citizen in the political sense. Citizenship is learned through 'education, socialization, exposure to politics, public

\footnotetext{
${ }^{54}$ Jocelyne Bourgon, 'Why Should Governments Engage Citizens in Service Delivery and Policy-Making?' in Focus on Citizens: Public Engagement for Better Policy and Services (OECD 2009) 201.

55 ibid.

${ }^{56}$ This is contrasted with a neo-liberal critique that challenges the idea of 'responsibilised' citizens and the measures taken by various democratic governments to reduce its support of social programs thereby abdicating its responsibility for its citizens' well-being. David Harvey, A Brief History of Neoliberalism (OUP 2005).

${ }^{57}$ Carol Pateman, Participation and Democratic Theory (CUP 1970) 42.

58 ibid 43.

${ }^{59}$ NC Saxena, 'What is Meant by People's Participation' in Andrea Cornwall (ed) The Participation Reader (Zed Books 2011) 32.
} 
life and day-to-day experiences' ${ }^{60}$ Benjamin Barber distinguishes between masses (as in 'government of the masses') and citizens. While masses do not govern themselves, citizens self-govern through participatory processes. ${ }^{61}$ Citizenship, as it is considered within a theory of participatory democracy, requires more than voting from the individual members of society; it requires that individuals actively engage in creating and implementing the political and legal rules and processes that shape their lives. This participation necessarily entails direct deliberation, action and contribution. As noted, in this sense, strong democracy is defined as a means of resolving conflict through a participatory process that engages citizens in a political community. ${ }^{62}$ This definition contemplates a public element to citizenship that obligates individuals to think and act in common.

The kind of participation contemplated by Pateman, Barber, and others can exist on a small scale as well as a national political scale, in terms of issue, forum and/or geography. In fact, the small-scale focus of much participation offers a sense of connectedness because people are more likely to be comfortable engaging in dialogue and reaching sustainable solutions on a small scale as opposed to being thrust in to large national forums where the issues and policy choices can be quite complex. ${ }^{63}$ In this regard, the local realm can arguably become an important site in which to develop collective action by cultivating 'face-to-face settings and manageably sized groups in which people talk, listen and think, and act together' ${ }^{64}$ Each encounter by a citizen provides an opportunity for the individual to gain self-confidence and knowledge of the community around them. This inculcates the ability to negotiate and deliberate which 'spill[s] over' from one area of life to another. This 'spillover' has a cumulative effect on the individual's ability to engage in different forums. ${ }^{65}$

Individuals also gain practice asserting democratic skills, which then potentially provide them with the confidence to participate in more complex spheres of decision-making. As this happens, participation becomes self-sustaining, because individuals voluntarily continue to use the skills and information obtained to engage further in debate and

\footnotetext{
${ }^{60}$ Lisa Veneklasen and others (eds) A New Weave of Power, People \& Politics - The Action Guide for Advocacy and Citizen Participation (Practical Action Publishing 2011) 31.

${ }^{61}$ Barber (n 32) 145-150.

62 ibid 151. A good example of the transformation from private individuals to public citizens through the assistance of a volunteer lawyer is Laura Nader's research on a community lawyer project in Connecticut (n 18).

${ }^{63}$ Orly Lobel, 'The Renew Deal: The Fall of Regulation and the Rise of Governance in Contemporary Legal Thought, (2004) 89 Minn L Rev 342, 383.

${ }^{64}$ Piomelli (n 40) 610.

65 ibid 384.
} 
deliberation about the laws and policies that affect them. ${ }^{66}$ Democracy is then strengthened by the fact that input from citizens and the resulting decision-making is derived from wide and frequent participation in a variety of contexts and forums. ${ }^{67}$ In considering the forum, the question that arises is whether the civil justice system can or should provide such a space in which individuals are able to speak and deliberate with a view to participating and developing collective efforts.

Ever greater citizen participation encourages the development of a community to the extent that individuals begin to think publicly as citizens, establish connections to other citizens, and, in feeling connected, are prompted to consider the 'welfare of the community as a whole' ${ }^{68}$ This process influences the setting of collective goals because all of the members of the community are given the opportunity to deliberate over the construction and development of those goals. ${ }^{69}$ Furthermore, related to the concept of community-building is the potential for individual self-transformation that is often associated with participation. By participating in various decision-making processes, individuals are able to fulfill certain 'innate and basic developmental needs for agency and for living up to one's potential' which reinforces the individual's sense of autonomy. ${ }^{70}$ However, by engaging in debate and dialogue, this autonomy is balanced against the benefits associated with individuals taking account of other worldviews and becoming attentive to the interests of others. Acknowledging that it is not possible to have both significant inequality and meaningful participation, ${ }^{71}$ another prospective benefit of participatory democracy is also the potential to create measures and forums that re-engage those members of society that are presently disenfranchised and/or disempowered. By developing avenues through which all citizens are given the opportunity to be heard and to affect decision-making, individuals can re-engage as members of a community who begin to think and act in common. This, in turn, works to

\footnotetext{
${ }^{66}$ Pateman (n 57) 43; In his discussion of strong democracy, Benjamin Barber distinguished between individuals lacking interest in politics versus a lack of interest in political decision-making. He argued that a myriad of surveys reflected individuals' interest in the later (n 32) 266.

${ }^{67}$ Hutchinson (n 35) 199.

68 Jocelyne Bourgnon, 'Responsive, Responsible and Respected Government: Towards a New Public Administration Theory’ (2007) 73(1) International Review of Administrative Sciences 7, 16.

${ }^{69}$ Barber (n 32) 146.

70 Audrey G McFarlane, 'When Inclusion Leads to Exclusion: The Uncharted Terrain of Community Participation in Economic Development' (2000) 66 Brooklyn Law Review 861, 909.

${ }^{71}$ For instance, according to Joshua Cohen, a Habermasian, discourse requires equal 'participatory rights' of all individuals such that each individual is able to 'propose issues for the agenda, propose solutions to the issues on the agenda, offer reasons in support of or in criticism of proposed solutions...[and] an equal voice in the decision'. Joshua Cohen, 'Reflections on Habermas on Democracy' (1999) 12 (4) Ratio Juris 385.
} 
negate the concept of the 'other' associated with exclusion and inequality and promote inclusivity.

\section{E. MEANINGFUL PARTICIPATION}

Notwithstanding the benefits associated with greater citizen engagement, there are challenges to the pivotal notion of 'meaningful participation'. First and foremost, there is an assumption that any or all participation is good participation. In her article on citizen participation, Sherry Arnstein disputes this idea. She maintains that participation must result in the real possibility for redistributing power and resources to those without resources or power if it is to be meaningful and legitimate. This presupposes that the participation will be effective and of consequence and that there is a willingness to share power and decision-making authority. Failing that, it is an empty process used by those with power to justify a course of action from which only certain members of society are likely to benefit. ${ }^{72}$

Given this requirement, if participatory democracy is to be effective and beneficial, it must account for the 'economic and social determinants' that potentially influence individuals in society and affect their ability to participate in a meaningful way. ${ }^{73}$ Lucie White suggests that, in many instances, the lack of power held by an individual or a particular group in society will not only prevent them being heard but even more fundamentally, prevent them from engaging in the discussion at all, thus making any notions of participation worthless. ${ }^{74}$ She maintains that for individuals who are truly subordinated in the sense that they are not in a position to express their problems either because they internalise the isolation and start to believe it is their fault, or are unable to articulate who is responsible for their situation, or further distrust the existing legal and political systems, it may be impracticable to suggest that there can be is meaningful participation without making changes to the allocation of social power, thereby increasing these individuals' power. $^{75}$

The consequence of not providing legitimate means by which power can be redistributed is that the participation remains 'cosmetic' in nature and potentially leads to the deeper marginalisation of certain stakeholders. ${ }^{76}$ This deeper sense of marginalisation results

\footnotetext{
${ }^{72}$ Sherry Arnstein, 'A Ladder of Citizen Participation' (July 1969) AIP Journal 216.

${ }^{73}$ Barber (n 32) 146; Roderick A MacDonald, 'Access to Justice and Law Reform \#2' (2001) 19 Windsor YB Access Just 317, 320. Pateman also relies on the Rousseauian requirement that participation contemplate economic equality and independence among citizens (n 57) 22.

${ }^{74}$ White (n 7).

75 ibid 758-60.

${ }^{76}$ Jaime Alison Lee, 'Can You Hear Me Now?: Making Participatory Governance Work for the Poor' (2013) 7 Harvard Law \& Policy Review 405, 406.
} 
from the entrenchment of the belief that only certain voices will be heard and only certain viewpoints are actually considered in the decision-making process. The likely outcome in this scenario is not only the continued exclusion of certain individuals and groups from the dialogue, deliberation and decision-making processes but also a further entrenchment of the belief that only certain individuals or groups are worthy of being heard. This results in continued disengagement by those who have been excluded historically. Thus, without the ability to impact the decision-making process, which necessarily implies that power is shared among the relevant stakeholders, participation may prove to be an empty engagement.

There is also a practical reality that, while the majority of individuals may 'possess the intuitive capacity to reason practically and therefore participate in political decisionmaking, it is naïve to assume communicative skills are distributed equally in society'. ${ }^{77}$ Moreover, even if it is assumed that all individuals are capable of participating, many individuals are busy with their own lives; they have neither the time nor the inclination to participate in various political processes. In such circumstances, there is a concern that participatory democracy will fail to achieve the critical mass of committed political citizens that is necessary to meet the ambitions of participatory democracy.

In addressing these concerns, there are several considerations. First, it should be noted again that, while not all citizens are prepared to participate in every decision-making process, what is important is that individuals understand that they can participate if they so choose: the requisite political and democratic institutions are designed for and encourage participation. The forums and contexts in which citizens participate are expanded and made accessible. Accepting the reality that not all citizens will participate in all decision-making processes, Benjamin Barber stated 'if all of the people can participate some of the time in some of the responsibilities of governing, then strong democracy will have realized its aspiration' ${ }^{78}$ By contrast, the failure of individuals to exercise willingly their power to participate may have less to do with their ability to do so and more to do with the fact that the present political system excludes all except certain specialists and experts who engage in the day-to-day political activity on behalf of the populace through a representative democracy and, in so doing, perpetuate a language and process that is unfamiliar to ordinary citizens. ${ }^{79}$

\footnotetext{
${ }^{77}$ Lorne Sossin, 'Redistributing Democracy: An Inquiry in Authority, Discretion and the Possibility of Engagement in the Welfare State' (1994) 26 Ottawa Law Review 1.

${ }^{78}$ Barber (n 32) 267.

79 ibid 152.
} 
Second, while individuals may be frustrated with politicians and political processes as they presently exist in a representative democracy, it does not mean that they do not want or are not interested in having a voice and role in the policies, rules and decisions that affect their daily lives and the lives of their communities. Experience would suggest that, to the extent that participation begets further and expanded participation, individuals want more participation and engagement, not less - so long as it is meaningful. However, as Arnstein and White note, fostering meaningful participation requires a re-distribution of power such that those who have been excluded historically are able to engage and those who have held power are prepared to relinquish it. Such a redistribution of power must take account of existing and inadequate socio-economic infrastructure, differences in knowledge bases and difficulties faced by certain groups who have been impacted by historical alienation and distrust. ${ }^{80}$ These considerations involve a gamble that those who have historically been disengaged and disempowered will be in a better position to place themselves in the conversation and ultimately the decision-making processes.

Given these challenges, if participation is to be effective, it is important that participation is fostered in a variety of forums and institutions that contemplate individuals participating on a local level. By offering a variety of forums and avenues for participation, individuals are able to gain the experience, skills, self-confidence and knowledge that promote further participation. However, this also means that participation will not look or operate the same in all areas of political, social and economic life. ${ }^{81}$ The very nature and structure of a particular participatory process may be influenced by theoretical frameworks of deliberative democracy and discourse theory, questions of operationalization, and differing participatory objectives. ${ }^{82}$

Moreover, it cannot be assumed that all individuals will participate in all forums or decision-making processes. Rather, the goal is that individuals are able to participate as they choose, particularly in situations where the policies being decided affect their lives and/or where "significant power is being deployed" ${ }^{83}$ against them. In these instances, it is important that the requisite political and legal institutions provide for and encourage engagement at a variety of different stages and in different ways. To accomplish this, there is also a need for corresponding systematic institutional participation within the existing democratic

\footnotetext{
${ }^{80}$ MacFarlane (n 70) 925.

${ }^{81}$ Hutchinson (n 35) 71.

${ }^{82}$ Menkel-Meadow (n 5) 11-112.

${ }^{83}$ Barber (n 32) 151.
} 
institutions. However, because many barriers to reform are context-specific, they must be examined within the particular forum in which greater participation is sought. At the same time, however, if participation is to be sustaining and meaningful, these reforms cannot be piecemeal, but rather system-wide and complementary. ${ }^{84}$

In considering participation within the specific context of the judicial system, there is a particular need to address the disconnect between the traditional legal framework, which focuses on an adversarial process undertaken by evenly matched legal professionals, and the modern realities that include significant numbers of self-represented litigants who are at serious disadvantage when engaging the traditional legal system. Unlike the professional lawyers, self-represented litigants suffer from a lack of knowledge and familiarity with the formalised processes and procedures as well as the presence of hostile players (ie lawyers, judges, and clerks). Given the modern reality facing many self-represented litigants, the question that will be examined in the next section is whether self-represented litigants can participate in a meaningful manner and what barriers must be addressed in order for them to participate.

The meaningfulness of citizens' engagement within these institutions will, in part, be judged by the actual impact that citizens have on the decision-making process. This is not to assume that in every instance the individual was able to change the outcome, but rather that the individual was able to 'have a say', and their voice was reflected in the decision-making process that ensued. Thus, an important component of this is the individual's belief that they were heard. ${ }^{85}$ Within a participatory context, engaging in dialogue and deliberation differs from engaging in traditional political debate. The former approach seeks to ensure that there is a considered exchange of different views and perspectives prior to making informed decisions. ${ }^{86}$ In accordance with this approach, a focus on listening as much as speaking would foster citizens' beliefs that their views and perspectives are not only being heard, but also being considered. In order to have such an impact, citizens as well as the decision-makers must be in a position to communicate; this involves more than simply speaking. Specifically, this involves 'receiving as well as expressing, hearing as well as speaking, and empathizing

\footnotetext{
84 ibid 265.

${ }^{85}$ The need to be heard underlies certain legal rules to questions of procedural fairness. One such approach suggests that the 'ideal procedural value' involves a 'fair hearing of contrary claims' in which competing claims are heard. Menkel-Meadow (n 5) 113. However, as will be discussed later in this paper, this particular procedural value loses significance when it is examined in the context of self-represented litigants.

86 Lisa Blomgren Bingham, 'Collaborative Governance: Emerging Practices and the Incomplete Legal Framework for Public and Stakeholder Voice’ (2009) 2 J Disp Resol 269, 278.
} 
as well as uttering'. ${ }^{87}$ Such communication plays an important role, not just in terms of decision-making, but also in terms of ensuring that individuals are able to engage in dialogue and deliberation before decisions are made. This component of meaningful participation highlights a second educational pre-requisite; namely, that individuals are provided with access to adequate information about the issues, processes and policies prior to being expected to deliberate.

\section{F. DEMOCRATIC PARTICIPATION AND ACCESS TO JUSTICE}

In the particular context of the civil justice system, considerable socio-legal research has suggested that when evaluating the fairness or justness of a legal process in which they were involved, litigants are more likely to express satisfaction with the legal process if they feel that they were able to both speak and be heard by the decision-maker. ${ }^{88}$ In many instances, the litigants' positive evaluation of the process (and presumably their ability to participate in the process) is less tied to a particular outcome in the proceeding and more tied to 'having a voice' ${ }^{89}$ Thus, by ensuring that the parties are able to express their viewpoint and be heard in a meaningful manner, the parties may begin to feel that the justice system operates fairly regardless of the particular result obtained and thereby be more willing to accept the outcome. ${ }^{90}$ Nowhere is this more significant than in the case of self-represented litigants who do not have an advocate speaking on their behalf and, therefore, are engaged directly in the adjudicative process. For self-represented litigants, the wish to have a voice and be heard has an immediate and direct impact on their perceptions about the legitimacy of the process and their interest in other forms of participation.

In the context of access to justice, the promotion of greater participation and engagement by individuals in the legal institutions and processes that affect them has the effect of strengthening the legitimacy of the justice system as part of the democratic process. Direct participation in the judicial system's law-making processes has the potential to corroborate the democratic aspects of this law-making process. Moreover, through meaningful participation in the development and administration of the laws that govern them, individuals will be in a better position to infuse those laws with their own conceptualisations

\footnotetext{
${ }^{87}$ Barber (n 32) 173.

${ }^{88}$ Nourit Zimmerman and Tom R Tyler, 'Between Access to Counsel and Access to Justice: A Psychological Perspective' (2010) 37 Fordham Urb LJ 473; Tom R Tyler, 'What is Procedural Justice?: Criteria Used by Citizens to Assess the Fairness of Legal Procedures' (1988) 22 Law \& Society Rev 103.

89 ibid.

${ }^{90}$ Tyler (n 88).
} 
of justice, freedom and equality; the impact of which potentially extends beyond the individual's particular circumstances.

By engaging directly with the rule-making and rule-administering institutions where principles of justice are established and implemented, individuals are in a better position to define justice in the context of their everyday life and in their encounters with public officials. ${ }^{91}$ In this sense, the gap between institutions and citizens will be better bridged and even abridged. This is accomplished in part by creating an 'enabling environment' in which the barriers to participation are removed. ${ }^{92}$ Creating an environment that expands the opportunities for citizens to participate is an important consideration in the civil justice context, where barriers have resulted in the continued exclusion of ordinary citizens from those legal institutions. This continued exclusion has led to extensive discussions and debates within the access to justice literature regarding the best means to address these barriers. Some of the barriers experienced by non-lawyers when attempting to access the civil justice system will be briefly discussed in a later section of this paper.

In examining whether access to justice policies might benefit from the infusion of participatory principles, it is important to canvas some of the objectives associated with the promotion of participation in order to determine whether such goals are consistent with, or achievable in the context of, access to justice initiatives. As noted, one of the goals associated with greater citizen participation is the collective acceptance of the decisions made in the course of participation. To the extent that individuals are able to provide opinions and deliberate on the issues that affect them, it is believed that they will be more willing to abide by the decisions that are made in this way. This does not mean that every decision will be reached through consensus, nor does it mean that all participating individuals will be satisfied with the result obtained in every situation, but it does mean that citizens are provided with the opportunity to deliberate, to take action and, in some instances, revisit issues previously decided upon when changes in society dictate. ${ }^{93}$

Thus, while the opportunity to be heard may seem like small or cold consolation for the party that loses their case; safeguarding the right to be heard contributes to the overall legitimacy of the justice system and citizens' confidence in the fairness of a legal process. This is particularly relevant in the context of decisions affecting self-represented litigants

\footnotetext{
${ }^{91}$ MacDonald (n 73) 319.

92 ibid 204.

${ }^{93}$ Barber (n 32).
} 
who are typically compelled to engage the civil justice system on their own and, in so doing, are unfamiliar with the processes and procedures used by the lawyers and judges.

\section{G. A CASE STUDY ON ACCESS TO JUSTICE FROM CONNECTICUT}

By way of confirmation, anthropological research conducted in respect of a participatory democracy project highlights the importance of a participating citizenry, the link between participation and community-building and the corresponding benefits associated with 'democratic participation' as a means for individuals to access justice in society. ${ }^{94}$

A community lawyer project was undertaken in Winsted, Connecticut. A lawyer was hired to assist members of the town in building civic education and participation at the local level. Local government did not hire the lawyer; she was funded through a private charitable organisation. The lawyer's task was to provide individuals in the community with the 'means by which they could translate personal concerns about the community into community action'. ${ }^{95}$ By providing individuals with information on the relevant law and procedures of local government, advising them on the use of media and lobbying, attending public meetings to ensure that officials followed procedures and compiling information regarding emerging issues in the community, the lawyer was able to assist citizens 'participate and become involved in the process of governing themselves'. In describing her role in the community, the lawyer stated that 'citizens without adequate information cannot exercise their rights and do not know what to expect from their government because they do not know what to demand' or presumably how to make demands. ${ }^{96}$ This lack of information was seen as directly impacting the citizens' capacity to engage in public dialogue and this, in turn, further undermined both the ability of the citizenry to participate in the decision-making process and the accountability of the governing officials.

The nexus between a lack of information about rights and processes and an individual's incapacity to engage in the democratic process at any level is relevant in the context of access to justice, and even more particularly relevant to self-represented litigants' participation in the civil justice system. The community lawyer project provides a concrete example where the dissemination of legal information and related skills was thought to have a direct impact on citizens' ability to participate and ultimately self-govern. In light of the fact that certain access to justice initiatives are directed at providing self-represented litigants with

\footnotetext{
${ }^{94}$ Nader (n 18) 505-508.

95 ibid 505

${ }^{96}$ ibid 506.
} 
legal information and advice so that they may navigate the civil justice system more effectively, it could be argued that such initiatives, like the community lawyer project, could promote opportunities for greater citizen participation by providing much needed information and advice about a particular legal process. Thus, to the extent that access to justice theory is informed by principles of participatory democracy, a question that arises is how access to justice initiatives might be developed to further promote meaningful participation. Related to this are questions about how such initiatives might dovetail with new approaches to lawyering, such as democratic lawyering, which assist individuals in asserting their own voice and engaging in the legal decisions and processes that affect them. The challenge in substantiating these initiatives is to account for the myriad issues that arise when examining the specific nature of an individual's participation in the civil justice system.

\section{H. CIVIL JUSTICE AND PARTICIPATORY DEMOCRACY}

The civil justice system is a significant component of a democratic society. ${ }^{97}$ In addition to resolving the private disputes of parties that come before them, courts and the judges who sit in these courts perform a distinctly political process within a democracy - namely rulemaking and rule-administering, whether it be in a private, public or constitutional context. Within common law jurisdictions, law-making by courts is a historical and institutional fact. In a paper on the legal profession, the Canadian Chief Justice McLachlin stated:

[C]ourts are seen as ways of compensating for the weaknesses of electoral decisionmaking and contributing to deliberative democracy by providing a forum where citizens can test laws for conformity to the fundamental values upon which the society is premised ... [these values] ... are fundamental to deliberative democracy, the goal of which is decisions that best represent the interests of the community as [a] whole. Independent courts thus emerge as an essential condition of democracy. ${ }^{98}$

However, there is the question of whether the work undertaken by lawyers and judges within the framework of the civil justice system is compatible with the commitments of a truly democratic society. In a democratic society, the civil justice system is engaged in the adjudication of legal rights and the delineation of legal duties and responsibilities by an

\footnotetext{
${ }^{97}$ Carrie Menkel-Meadow has commented that total access to courts that run well and are inclusive ensure access to a leading democratic institution. See Carrie J Menkel-Meadow and Bryant G Garth, 'Civil Procedure and the Courts' in Peter Cane and Herbert M Kritzer (eds) The Oxford Handbook of Empirical Legal Research (OUP 2010).

${ }_{98}$ Beverly McLachlin, 'Judges in a Multicultural Society' (paper presented at Chief Justice of Ontario's Advisory Committee on Professionalism on the Legal Profession, 'Inaugural Colloquium on the Legal Profession,' 20 October 2003, Faculty of Law, University of Western Ontario) at 3-5-3-6.
} 
independent appointed judiciary. Courts, through the creation and application of law, construct the ways in which individuals' real life problems are situated within a particular legal framework and then subjected to a range of possible solutions that have been established within that same legal framework. In the course of this process, the lawyers and judges who participate in the justice system engage in critical political discussions that shape not only the content of the laws but also the underlying values and norms adopted by and reflected in society. One manifestation of this norm creation occurs in the context of precedental judgments whereby judges are not only resolving private parties' disputes but also engaging in the regulation of future behavior and the future outcome of similarly situated parties in similarly situated cases or negotiated settlements. ${ }^{99}$

The civil justice system articulates citizens' legal rights and duties. In some instances, the system will protect citizens' rights vis-à-vis the state. However, the judicial process is criticised as being inconsistent with democratic principles: while it may be 'for the people,' it is certainly not 'by the people'. ${ }^{100}$ As previously noted, the civil justice system has historically involved a conversation between the judiciary and an elite legal profession that has precluded direct participation by ordinary citizens except in rare instances. Notwithstanding the increase in self-represented parties and attempts to make the institutional processes user-friendly, the legal language spoken in the civil justice system continues to be the specialist vernacular of lawyers; all of this makes it very difficult for ordinary citizens to participate in the process without legal representation. Despite this difficulty, growing numbers of individuals are compelled to proceed without legal representation. ${ }^{101}$ As a result, many self-represented litigants express anxiety, frustration, powerlessness, and ultimately disengagement when they appear in court without legal assistance. ${ }^{102}$ Moreover, to the extent that we acknowledge the political nature of the adjudication process and the important role that it plays in a democracy, the fact that a significant portion of individuals are compelled to enter this process overwhelmed and under-prepared, suggests a crucial failing of democracy.

\footnotetext{
${ }^{99}$ Farrow (n 2).

${ }^{100}$ Some maintain that because the law favours maintaining the status quo and the courts apply the law, the legal process in the judicial system forms an 'integral part of the general apparatus which holds the existing governmental arrangements in place and places a series of obstacles in the way of those who struggle to bring about political change'. Hutchinson (n 35) 167; see also Allan Hutchinson, 'A "Hard Core" Case Against Judicial Review', 122 Harvard Law Review Forum 1 (2008).

${ }^{101}$ Michael Trebilcock, Anthony Duggan and Lorne Sossin (eds), Middle Income Access to Justice (University of Toronto Press 2012).

102 MacFarlane (n 8).
} 


\section{OPERATIONAL AND ATTITUDINAL BARRIERS TO ACCESS}

Operational barriers inherent in civil justice procedures make it difficult for non-lawyers to manoeuvre through the system. Court staff are not typically in a position to provide extra assistance to self-represented parties who are unfamiliar with the court processes. Moreover, this assistance has historically been viewed as involving the provision of legal advice, which only lawyers are regulated to provide in most jurisdictions. Complicating matters further is the fact that individual courts may invoke different practices and procedures that are only familiar to the lawyers who regularly attend that particular court. In light of these concerns, there have been some efforts to re-design court processes in order to ensure that the civil justice system is more user-friendly for non-lawyers. For example, streamlined procedures and higher monetary limits in small claims courts where most self-represented individuals appear; the inclusion of more duty counsel who can facilitate a self-represented litigants' experience in the civil justice system; and the simplification of court forms which incorporate plain language so that non-lawyers can complete the forms without legal assistance, as well as the ability to file the forms electronically. These are some of the operational reforms that have been undertaken. However, the continuing dilemma is that these initiatives have been slow to be implemented, are piecemeal at best when broader overhauls are required, and have not been uniformly adopted by all courts. As such, operational and information-based barriers as well as procedural barriers to participation remain prevalent in the civil justice system.

Added to these concerns are certain attitudinal barriers prevalent among the key players in the civil justice system. A portion of the legal profession, along with some members of the bench, characterise self-represented litigants as vexatious or frivolous litigants as well as the cause of much delay in the judicial system. ${ }^{103}$ Moreover, on occasion, the legal profession and its regulator have been criticised for their resistance to the development of programs that would assist individuals to better represent themselves when faced with a legal problem. ${ }^{104}$ Both the legal profession and its regulator have characterised this resistance as protecting litigants from the risks associated with receiving incorrect or

\footnotetext{
${ }^{103}$ Rhode (n 11) 402-403.

104 ibid 81. It is worth noting that in Ontario, the Law Society of Upper Canada (LSUC), the legal profession's regulatory body, was resistant to relaxing the need for conflict of interest searches in the self-help setting notwithstanding that such a course of action would allow volunteer lawyers to meet with more individuals during the course of a day as they did not need to wait for the results of conflict searches. Although the LSUC's conflict requirements were eventually relaxed for lawyers volunteering at the self-help centre, the process by which the LSUC was persuaded to change its position took a significant amount of time and drew on the already limited resources of the pro bono organisations that were required to make submissions to the LSUC. See also Paul Paton, 'Between a Rock and a Hard Place: The Future of Self-Regulation - Canada between the United States and English/Australian Experience' Journal of the Professional Lawyer in Canada 87 regarding his criticism of the Law Society of Upper Canada's position on the regulation of paralegals.
} 
misleading advice. However, a different explanation for the legal profession's resistance is linked to the profession's concerns about unrestricted competition as a result of non-lawyers being better equipped to handle legal matters and thus no longer requiring legal representation. This is a perceived threat to the legal profession's longstanding monopoly on the provision of legal services. ${ }^{105}$ Changing these attitudes to include an approach that contemplates greater accommodation of self-represented parties runs contrary to the legal profession's entrenched ideas about how the adversarial system works and the lawyer's role within that adversarial system.

Although based on different concerns, members of the judiciary do not escape some of these criticisms. Again, research data collected from self-represented litigants suggests that judges can seem unsympathetic and even antagonistic toward self-represented litigants who do not appear to understand the nature of the proceedings or the legal processes in their courtroom. ${ }^{106}$ In fairness to many judges who are confronted with significant numbers of selfrepresented litigants on a daily basis, they may be unsure of how to balance the selfrepresented litigants' needs in the courtroom with their own obligation to remain impartial as per their traditional role in the adversary system. ${ }^{107}$ Regardless of the underlying motivations, the results are the same; self-represented litigants often feel disempowered within the civil justice system. The challenge is to find ways to make the judicial system more hospitable to self-represented litigants without compromising the integrity of the justice system. Accordingly, in light of the persistent barriers referenced above and the entrenched attitudes held by key players within the civil justice system, the continued exclusion and disengagement of non-lawyers raises questions about whether even well informed selfrepresented litigants could be in a position to participate fully and effectively.

\footnotetext{
105 Rhode (n 11) 81.

${ }^{106}$ In one recent and extreme example, an American judge ordered that the sheriff attending in court give the self-represented accused a shock through the accused's security ankle bracelet because the judge felt that the individual was wasting the court's time by raising superfluous arguments. The judge was immediately removed from the bench by the state bar. See Richard Zorza, 'Judge Orders Self-Represented Litigant to be Given Electric Shock' (Richard Zorza's Access to Justice Blog, 9 September 2014) <http://accesstojustice.net/2014/09/09/judge-orders-self-represented-litigant-given-electric-shock/> accessed 17 February 2015.

${ }^{107}$ Rhode (n 11) 403; some commentators note that many judges are unclear about how to help self-represented litigants within the adversarial system without appearing biased. For instance, Jona Goldschmidt observes that, in contrast to the operating premises of the traditional adversarial system, in cases involving an SRL and a represented party, judges are faced with the difficulty of providing impartial justice on an uneven playing field. The SRL, who often represents herself out of necessity due to insufficient funds, must navigate a confusing legal process without the same familiarity or expertise about the rules of game that will allow her to present her issues effectively and substantiate her case. If judges remain passive and merely rule on procedural violations, SRLs have a substantial disadvantage and the truth-finding function of the hearing is severely curtailed'. Jona Goldschmidt, 'Lawyers' Perceptions of the Fairness of Judicial Assistance to Self-Represented Litigants' (2012) 30 Windsor YB Access Just 139, 171.
} 


\section{J. POSSIBILITY OF MEANINGFUL PARTICIPATION IN THE CIVIL JUSTICE SYSTEM}

In addition to various informational, procedural and operational barriers that impede participation by non-lawyers, there is also a substantive question about whose interests the civil justice system is in a position to serve. This question is particularly pertinent for those individuals attempting to assert a social justice agenda within the traditional court system. To the extent that the justice system only serves certain groups' needs, enhanced participation by excluded groups may be characterised as empty or cosmetic. Notwithstanding the significant and growing number of self-represented litigants engaged in the civil justice system, the existing legal system and the organisation of the legal profession have been criticised as being primarily designed to resolve the private disputes of corporations and wealthy individuals able to afford legal representation. ${ }^{108}$ In answering the question of whether '[Canada] has adequate access to justice', Chief Justice McLachlin commented that 'the answer is no. Among those hardest hit are the middle class and the poor. We have wonderful justice for the corporations and for the wealthy'. ${ }^{109}$ In this regard, courts are characterised as 'venues that simply distribute power to power'. ${ }^{110}$

In this regard, Gabel and Harris contend that the legal system and, more particularly, the court system serves to legitimate the existing power structures in society. This criticism is further reflected in the claim 'the legal process is strongly aligned with the interests of the established order which is better able to access its formidable authority and institutional resources in order to resist change and/or to divert those transformative efforts into debilitating and decelerating channels'. ${ }^{111}$ Moreover, the adversarial structure of the justice system and the assumptions that underlie this structure - that each party has a trained legal representative who will advocate on the party's behalf and from which a just result will be derived - starts to break down when only one party has an advocate who is familiar with the substantive law and legal procedures. In fact, the traditional adversarial framework becomes distinctly unfair when only one party is in a financial position to retain an advocate and, thus, unlikely to encourage meaningful participation.

\footnotetext{
${ }^{108}$ Stephen Wexler, 'Practicing Law for Poor People' (1970) 70 Yale LJ 1049.

${ }^{109}$ Michael McKiernan, 'Lawyers Integral in Making Justice Accessible: Chief Justice Beverly McLachlin' (Law Times, 21 February 2011) <http://www.lawtimesnews.com/201102218262/HeadlineNews/Lawyersintegral-in-making-justice-accessible-McLachlin> accessed 17 February 2015.

${ }^{110}$ Farrow (n 2) 28.

${ }^{111}$ Hutchinson (n 35) 156.
} 
Since the civil justice system is built on the resolution of individual cases, ${ }^{112}$ there is also continued scepticism over whether it is possible for individuals who are already disempowered or disengaged from society to have any meaningful impact on the existing social and political systems through individual litigation cases. The very fact that individuals' claims are isolated in the sense of being individualistic suggests that the system has a limited ability to reform the social and political systems. This concern is magnified when the individual attempting to engage is a self-represented litigant. Thus, even if individuals are able to articulate a claim regarding their rights in the civil justice system, the overall impact of such a case may be minimal. To the extent that this portrayal is reflective of how the judicial system operates, the provision of information or skills that allow an individual to assert a claim and articulate a position in the civil justice system may fall victim to Arnstein's criticism regarding empty participation which is reflected in an inability to redistribute power and resources. ${ }^{113}$

\section{K. SELF-HELP AND CITIZEN PARTICIPATION}

Notwithstanding the criticisms that are leveled at the structure and organisation of the civil justice system and individuals' ability to participate directly in the civil justice system, the question that remains is whether an access to justice initiative such as self-help legal services can play a role in facilitating participation. Moreover, given the principles and objectives of participatory democracy, whether an initiative such as self-help legal services are able to facilitate or enhance participation in a broader societal context. The criticisms raised in respect of the civil justice system would tend to suggest that meaningful participation by nonlawyers is minimal and a very challenging endeavor for any self-represented litigant. However, being cognisant of the educative function of participation and observing a concrete example of this function in the case of the Connecticut community lawyer, it is possible to see how an access to justice initiative such as self-help could, in theory, expand and multiply the opportunities for citizen participation.

The purpose of civil law self-help centres is to provide self-represented litigants with the information and skills necessary for them to pursue their own legal issues without legal representation. ${ }^{114}$ The provision of legal information and/or skills arguably allows the

\footnotetext{
112 This is notwithstanding the emergence of class actions in specific legal contexts.

${ }^{113}$ Arnstein (n 72) 216.

${ }^{114}$ There are several self-help legal centres in Canada as well as hundreds in the United States that provide a variety of legal services and information to self-represented individuals, typically on a 'first come, first served' basis. The development of these centres has been linked to a corresponding decrease in legal aid support and
} 
individual to engage with the civil justice system in a more, if not perfectly meaningful manner. By obtaining information that helps to demystify the substantive law as well as legal procedures, individuals might feasibly be in a better position to convey their position to opposing parties as well as members of the judiciary. ${ }^{115}$ Moreover, through direct participation in the legal process, the individual is afforded an opportunity to frame the legal problem in a manner that is more relevant to his or her life. To the extent that this results in the construction of laws that are more consistent with the organisation of ordinary citizens' lives and reflective of their own conceptualisation of law and justice, self-help could play a role in advancing individuals' meaningful participation.

One of the challenges in this regard will be to ensure that while civil law self-help legal services continue to provide individuals with the legal tools necessary to engage in deliberation and decision-making about civil law, the provision of legal advice and information will not result in the continued dependency on lawyers by non-lawyers. ${ }^{116}$ In other words, civil law self-help centres must provide individuals with the information necessary to engage in the civil justice system and, at the same time, support the individuals in their efforts to disabuse themselves of the language of experts. In this regard, the existing framework, and those who act within it, will need to accommodate a new legal language that is nurtured and adopted by the citizens themselves rather than dominated by lawyers and judges. This discussion is theoretical in the sense that it assumes that to the extent that selfhelp centres provides legal information, skills, and tools, individuals will be able to make use of the information and, in so doing, participate in and ultimately influence the development of the civil law. Given the existing legal framework with all of its traditional notions of adversarial proceedings and professionalised participants, the question that remains is whether this might be practically achievable. ${ }^{117}$

\footnotetext{
increase in the numbers of individuals who are unable to secure legal representation. Merran Lawler, Jeff Gidding and Michael Robertson, 'Opportunities and Limitations in the Provision of Self-Help Legal Resources to Citizens in Need' (2012) 30 Windsor YB Access Just 185, 188.

115 Of course, in accordance with Arnstein's (n 72) comments about power, this requires that the key players in the system relinquish some of their power over both the processes and the language used in the justice system.

${ }^{116}$ Marc Galanter, 'Justice in Many Rooms' (1981) 19 Journal of Legal Pluralism 1, 18.

${ }^{117}$ Interestingly, in one unique setting, participation by members of a tribal community in the local justice system resulted in the development of a system of laws that were directly related to the community members' needs and concerns. Over four hundred years ago, the Zapotec Indians of Mexico were granted a right by the Spanish to administer their own local courts. The local court hears cases involving family, land, and debt, among other matters traditionally classified as 'civil' law matters. Democratically-elected individuals in the community administer the court system. Plaintiffs play an active role in the proceedings in which there are no lawyers and, unlike in North American judicial systems, there are no 'typical' plaintiffs. In other words, the plaintiffs are male, female and derive from all socio-economic levels in the community. The plaintiffs 'readily resort to litigation but regularly use compromise to find remedies'. The result has been the development of a
} 
It has been further noted that the 'proliferation' of regulation and administrative bodies that govern individuals' lives in modern society have not simplified life for the ordinary citizenry. Instead, it has made it more difficult for "people to know which agency to approach with what problems, or how to organize their information and evidence for presentation'. ${ }^{118}$ Given the proliferation of these various administrative and regulatory bodies and institutions, it is important that information provided through initiatives such as self-help legal services expand beyond technical information to the skills and tools necessary to engage in these institutions. Similar to the services provided by the community lawyer in Connecticut, information made available to self-represented parties must ensure that individuals are better able to understand their rights and responsibilities and identify the appropriate forum and process for addressing same.

By providing individuals with information about the legal and political options and forums available to them in a broader educative sense, like the community lawyer working in the Connecticut community referenced above, self-help legal services offer an opportunity for individuals to gain legal knowledge as well as the practical means to access the different political and democratic institutions that impact their lives. For example, the individual may gain knowledge about which forum or process they need to engage as well as how to gather and organise information that they may need to submit in a particular institutional setting, and then present such information to an adjudicator. The inclusion of the practical means to participate further encourages opportunities for citizen participation outside of the specific context of the civil justice system and this, in turn, promotes further engagement with a variety of government processes, forums and different decision-making capacities.

\section{CONCLUSION}

Participatory democracy has been described as the politics of amateurs, whereas representative democracy involves the politics of specialists. ${ }^{119}$ One of the themes that I have discussed has involved the idea that the administration of law as a process has historically

\footnotetext{
body of laws that are directly linked to and arguably reflective of the users' needs rather than abstract concepts and principles derived from the legal reasoning of judges and arguments of lawyers. The results obtained through litigation generally reflect the community's desire to find a remedy for the dispute rather than uphold an abstract principle of law. However, notwithstanding the obvious limitations of this particular justice system, it is provides a useful point of discussion - by having meaningful access to justice that both contemplates and provides for direct involvement in the dispute resolution system, the citizens in the Zapotec community actively participate in the definition of justice, the administration of justice and in so doing, they are able to participate in the process of self-governing. Nader (n 19).

118 ibid 508.

119 Barber (n 32) 152.
} 
been the exclusive domain of specialists. However, when a self-represented litigant seeks assistance from a legal self-help centre, the understanding is that the individual is proceeding without the traditional representation of expert legal counsel. As a result, self-represented litigants who do not rely on an intermediary (eg a lawyer or paralegal) to bring their matter before the court have an opportunity to directly impact the legal decision-making that is relevant to their particular legal problem, consistent with the 'politics of amateurs' rather than the 'politics of specialists'. This opportunity to be heard and potentially influence the decision-making process can impact the individual's perceptions about the fairness and justness of the particular process. Thus, to the extent those individuals believe that they were provided with an opportunity to 'have a say', they may be more inclined to believe they are entitled to a say and, more importantly, may begin to exercise a right to have a say in other contexts.

Underlying these observations about the potential role of self-help is the assumption that direct participation by self-represented litigants must be supported by significant civil justice system reforms on both a procedural and substantive level. These reforms would need to include the measures necessary to ensure that self-represented individuals are able to engage in the civil justice system in a meaningful manner. The implementation of such measures would entail dismantling various operational and procedural barriers that presently impede self-represented litigants from participating and developing new procedures and processes that take account of non-lawyers' needs and abilities. As noted by Benjamin Barber, these reforms cannot be implemented in a piecemeal fashion. These types of civil justice reform must also balance the requirement that the legal processes be fair and consistent with the rule of law and, at the same time, take account of the practical realities of administering a legal system that includes a significant number of self-represented parties who are unfamiliar with those very legal processes or language. In addition, there is a need for a corresponding shift in attitudes of key insiders such as lawyers, judges and court staff. This shift involves fundamental questions about the continued adherence to the existing adversarial framework, the role of the lawyers and judges within a reconstituted justice system, and the role of self-represented litigants within this framework.

The first part of this paper made reference to a broader concept of access to justice that contemplates citizen participation in all of the law-making and law-administering institutions in society. In his article on access to justice, MacDonald stated 'access to justice means most of all that people are able to find justice in their everyday encounters with public 
officials; it is about transparency, accountability, integrity and ethics in the delivery of public services'. ${ }^{120}$ This interpretation of access to justice led MacDonald to question how it might be possible to provide opportunities for ordinary citizens to engage fully in the judicial, legislative and administrative processes through which law is made and administered. ${ }^{121}$ Through participation in one aspect of society, citizens obtain the information, tools, and skills sets necessary to allow them to participate in other aspects of society. While the practices and procedures followed in the civil justice system may be very different from the procedures adopted by city council when holding public meetings, the fact is that by participating in one forum individuals gain confidence, tools, and skills with respect to how political and democratic institutions are administered and how they might subsequently engage with other institutions or in other decision-making processes. This reinforces their willingness to further participate and empowers them to engage with other aspects of society in which they may wish to impact decision-making. It is in this way that Pateman suggests that participation becomes self-sustaining. ${ }^{122}$ Moreover, individuals' engagement in decisionmaking processes fulfills important needs related to 'voice', self-government, and community-building - all of which are important aspects of a healthy democratic society.

One limitation on this element of participatory theory pertains to the situation where individuals have a negative experience in the course of representing themselves in the civil justice system. Many of the self-represented litigants who attempt to manage their own legal matters, even with assistance from self-help centres, will lose their cases and, in the course of losing their case, be subject to significant consequences; these include monetary awards and judgments, loss of a home or property, and/or unfavourable custody arrangements. In these instances, the question remains whether an individual's negative experience in the particular context of the civil justice system will override the individual's willingness to participate in other capacities. This potential limitation on participation is heightened by the practical reality that many self-represented litigants do not choose to represent themselves, but are compelled to do so because they cannot afford legal representation. Given the choice between participating in the civil justice system by representing themselves or having counsel, a significant portion of self-represented litigants would choose to retain counsel. ${ }^{123}$ In light of

\footnotetext{
${ }^{120}$ MacDonald (n 73) 319.

121 ibid 319.

122 Pateman (n 57) 24.

${ }^{123}$ The author's ongoing empirical research with self-represented litigants who have made use of self-help legal services reflects this assertion. In qualitative interviews with self-represented litigants, the majority of individuals indicate that they would hire a lawyer if it were economically feasible.
} 
this consideration, the question of the significance of a negative experience on future participation remains an important part of the discussion on access to justice initiatives and citizen participation. While it does not provide a complete answer to the potential impact that a negative experience may have on further participation, a partial response to this issue may lie in the strength of the measures that are taken to ensure that the civil law procedures are fair, transparent, and accessible to all individuals.

While access to justice initiatives such as self-help legal services work within a less than perfect judicial system that is in need of further democratic reform, there are educative and empowering benefits that could foster further citizen participation through selfrepresentation in curial settings. To the extent that this is a goal worth pursuing, the challenge going forward is to examine how a broader conceptualisation of access to justice might incorporate principles of participation and how those principles might be further reflected in the policy decisions and related programs that are developed to enhance access. This is a demanding but worthwhile challenge that can reap considerable benefits for those marginalised in a society that relies more and more on litigation and courts as a way of building a more just and inclusive society. 